\title{
Symptomatology and Molecular Characterization of Fungi Associated with Sigatoka Leaf Spot Disease of Banana in Kerala, India
}

\author{
Milsha George $^{1 *}$, K. Anita Cherian ${ }^{1}$, S. Beena ${ }^{1}$ and P.M. Namitha ${ }^{2}$ \\ ${ }^{1}$ Department of Plant Pathology, College of Horticulture, Vellanikkara, Thrissur, \\ Kerala, India \\ ${ }^{2}$ Department of Plant Pathology, Banana Research Station, Kannara, Thrissur, Kerala, India \\ *Corresponding author
}

\section{Keywords \\ Sigatoka leaf spot complex, Perithecia, ascospores, ITS - rDNA, Amplicons, Mycosphaerella emusae \\ Article Info \\ Accepted: \\ 07 January 2018 \\ Available Online: \\ 10 February 2018}

\section{A B S T R A C T}

Sigatoka leaf spot disease of banana is spreading at a faster rate causing a serious threat to banana cultivation in Kerala, the southern most state of Indian peninsula which enjoys a humid tropical climate. A survey was conducted under different agro-climatic zones prevailing in the state to study and document the symptomatology and etiology of the pathogen inciting Sigatoka leaf spot disease of banana occurring in the state of Kerala. The disease was noticed in most of the commercially grown varieties of banana viz., Nendran (AAB), Grandnaine (AAA), Njalipoovan (AB) and Robusta (AAA) throughout the year, but become more severe with the onset of rains. The symptoms initially appeared as small light green to yellow dashes on the lower surface of the leaf which was visible only when the leaves was held against sunlight. This later changed into faint brown visible streaks. During the next stage, these streaks turned rusty brown on the adaxial surface of the leaves, which then developed into oval or elliptical brown spots with greyish centre surrounded by definite dark brown border with black pin head like fruiting bodies embedded in it. Upon heavy infection, the spots coalesced leading to complete necrosis of the leaves thereby destroying the functional green tissues of the leaves. This resulted in drastic reduction in the photosynthetic area causing an impact in yield reduction. The disease also resulted in premature ripening of the fruits affecting the fruit quality. The microscopic observations of these necrotic lesions revealed the presence of flask shaped telomorphic fruiting bodies called perithecia bearing asci and ascospores. The presence of the pathogen wasfurther confirmed by amplification of the ITS- rDNA region of the fungus using ITS 1 and ITS 4 primers which yielded amplicons of size ranging from 540$580 \mathrm{bp}$. The amplicons were further sequenced and blasted in NCBI which showed 97 $100 \%$ sequence homology to Mycosphaerella emusae. Hence, the pathogen inciting Sigatoka leaf spot diseases on banana in Kerala was identified and confirmed as Mycosphaerella emusae.

\section{Introduction}

Banana is an important fruit crop grown in tropical countries. Though the crop is grown under diverse agroclimatic conditions, its cultivation is threatened by different diseases of which Sigatoka leaf spot disease caused by Mycosphaerella spp. is a serious constraint to 
banana cultivation worldwide. In India, the this disease is more prevalent in states of Kerala, Tamil Nadu, Karnataka, Maharastra, Gujarat, West Bengal and Tripura where the maximum disease severity of $90-100 \%$ was reported on different cultivars.

Globally, three species of Mycosphaerella viz., Mycosphaerella fijiensis, M. musicola and $M$. eumusae have been reported to cause different Sigatoka leaf spot diseases like black sigatoka, yellow sigatoka and emusae leaf spot respectively (Arzanlou et al., 2007).

The symptoms produced by all the three Mycosphaerella spp. on banana plants appeared to be very similar which complicates the identification of the pathogen based on visual symptoms (Surridge et al., 2003).

Apart from this, the difficulty to culture the pathogen on artificial media limits the identification of the pathogen based on fungal structures. Therefore, it is essential to develop culture independent, specific molecular detection techniques for the identification of particular species of pathogen associated with Sigatoka leaf spot complex.

The reports on the rapid replacement of yellow Sigatoka disease by black Sigatoka in many tropical coastal regions (Jones, 2000) and the presence of emusae leaf spot caused by Mycospaherella emusae in South India (Carlier et al., 2000b) necessitated the need to identify the pathogen associated with Sigatoka leaf spot disease in Kerala.

Therefore, in the present study a detailed survey was carried out in various agroclimatic zones of Kerala to understand the symptomatology and the particular pathogen associated with Sigatoka leaf spot disease complex occurring in banana especially in variety Nendran which is the most commercially growing variety of Kerala state.

\section{Materials and Methods}

\section{Survey}

A survey was conducted during 2016-2017 under different agro-climatic zones prevailing in the state viz., Malapuram (Northern zone), Palakkad (Northern zone), Thrissur (Central zone), Ernakulam (Central zone), Wayanad (High range zone), Trivandrum (Southern zone) to study in detail the symptomatology, occurrence, severity and the pathogen associated with Sigatoka leaf spot disease complex. From an orchards of minimum 400 plants, 20 plants were randomly selected and scored to record the disease severity index and youngest spotted leaves. The leaves with different symptoms were collected from plants of different age groups and brought to the laboratory for further studies of the pathogen associated with the disease.

\section{Morphology of the sexual stage of pathogen}

The leaf sections having mature spots with stage 6 lesions were cut into $2 \mathrm{~cm}^{2}$ bits. These bits were dipped in $10 \%$ potassium hydroxide (which decolorizes plant tissue) (Udugama, 2002) overnight which was then washed 1-2 times in sterile water. The bits were then blot dried and the lesions were scrapped using a needle. The scraping were then transferred to a slide with a drop of lactophenol cotton blue stain and was observed under microscope for fungal structures.

\section{Molecular characterization}

\section{Isolation of DNA}

Molecular characterization of the pathogen associated with Sigatoka leaf spot disease of Kerala was carried out by isolating fungal DNA using DNeasy Plant Mini Kit from the lesions of the leaf samples (Surridge et al., 2003) collected during the survey followed by 
PCR amplification and sequencing of the ITS region of the isolated fungal DNA. About 100 $\mathrm{mg}$ of the leaf tissue containing mature lesions was homogenized using liquid nitrogen and the powdered tissue was transferred to a micro centrifuge tube. Four hundred $\mu$ of buffer AP1 was added and inverted for one minute. Four $\mu$ l of RNAase A solution was added and vortexed vigourously for 30 seconds. The homogenate was incubated at $65^{\circ} \mathrm{C}$ in a water bath for $10 \mathrm{~min}$. During incubation the homogenate was mixed 2 or 3 times by slowly inverting the tube. $130 \mu \mathrm{l}$ AP2 buffer was then added to the lysate, mixed well and incubated on ice for $5 \mathrm{~min}$. The lysate was pipetted into the QIAshredder Minispin column placed in a $2 \mathrm{ml}$ collection tube and centrifuged at 14000 rpm for $2 \mathrm{~min}$. The flow through liquid was collected into a new tube without disturbing the cell debris pellet. 1.5 volumes of AP3 buffer was added to the cleared lysate and was mixed by pipetting. Six hundred and fifty $\mu 1$ of the mixture was transferred into DNeasy Mini Spin column placed in a $2 \mathrm{ml}$ collection tube. The mixture was then centrifuged for one min at $8000 \mathrm{rpm}$ and the flow through liquid was discarded. The column was then placed into $2 \mathrm{ml}$ collection tube, and $500 \mu \mathrm{l}$ of AW buffer was added, centrifuged at $8000 \mathrm{rpm}$ for one min and the flow though liquid was discarded. Again $500 \mu \mathrm{l}$ of AW buffer was added to the column and centrifuged at $14000 \mathrm{rpm}$ for 2 min to dry the membrane. The column was transferred to a new $1.5 \mathrm{ml}$ tube and $100 \mu \mathrm{l}$ of AE buffer was added directly into the DNeasy membrane and incubated at room temperature $\left(15-25^{\circ} \mathrm{C}\right)$ for $5 \mathrm{~min}$. The column was then centrifuged at $8000 \mathrm{rpm}$ for one min to elute the DNA. The eluted DNA was stored at $4{ }^{\circ} \mathrm{C}$.

\section{Agarose gel electrophoresis}

The quality of the DNA isolated was checked using agarose gel electrophoresis. One $\mu \mathrm{l}$ of $6 \mathrm{X}$ gel-loading dye was added to $5 \mu 1$ of DNA and was mixed well by pipetting. The samples were loaded to $0.8 \%$ agarose gel prepared in $1 \mathrm{X}$ TAE containing $2 \mu \mathrm{l}$ ethidium bromide. Electrophoresis was performed with $1 \mathrm{X}$ TBE as electrophoresis buffer at $75 \mathrm{~V}$ until bromophenol dye front had migrated to the bottom of the gel. The gels were visualized in UV transilluminator (Genei) and the image was captured under UV light using Gel documentation system (Bio-Rad).

\section{PCR amplification and sequencing}

PCR amplification was carried out by amplifying the ITS region of the isolated DNA using ITS 1 and ITS 4 primers. The PCR amplification reactions were carried out in 25 $\mu 1$ reaction volume which contained $12.5 \mu 1$ of PCR master mix (Takara EmeraldAmp ${ }^{\circledR}$ GT PCR Master Mix), $0.5 \mu$ l ITS 1 primer, $0.5 \mu 1$ of ITS 4 primer, $2 \mu$ l of DNA and $9.5 \mu$ lof distilled water. The PCR reaction conditions were standardized. The optimum reaction conditions were: initial denaturation of $94^{\circ} \mathrm{C}$ for $3 \mathrm{~min}$ followed by 35 cycles of denaturation at $94^{\circ} \mathrm{C}$ for $45 \mathrm{sec}$, annealing at $60.4^{\circ} \mathrm{C}$ for $45 \mathrm{sec}$, elongation at $72^{\circ} \mathrm{C}$ for 1 min with final elongation at $72{ }^{\circ} \mathrm{C}$ for $10 \mathrm{~min}$. Ten $\mu$ I PCR product were loaded along with 100 bp ladder on $1.2 \%$ agarose gel prepared in $1 \mathrm{X}$ TAE containing $2 \mu \mathrm{l}$ ethidium bromide. The gels were visualized in a UV transilluminator (Genei) and the image was captured under UV light using Gel documentation system (Bio-Rad). The amplicons were eluted using gel elution kit and the eluted amplified product was sent to Agri Genome Pvt Ltd. for sequencing.

\section{Phylogenetic analysis}

The sequence data set based on the ITSrDNA region of the pathogen associated with Sigatoka leaf spot disease of banana and other reference sequences were retrieved from NCBI Genbank database (USA) using BLAST algorithm and were compared. Multiple 
sequence alignment was done using Clustal Omega and phylogenetic tree was constructed in Mega6 using UPGMA tree construction method.

\section{Results and Discussion}

\section{Survey}

The details of the preliminary survey conducted at different agro-climatic zones of Kerala are presented in Table 1. The disease severity index was found more in Thiruvanathapuram district with a Disease severity index of 27.40. The disease was found to be more intense with the onset of rains. The disease symptoms on the commercially grown varieties of viz., Nendran (AAB), Grandnaine (AAA), Njalipoovan (AB) and Robusta (AAA) were documented and observed for symptom development. The symptoms were expressed in six stages (Fig. 1) as described below. Disease symptoms observed initially were designated as stage 1 as yellow pigmented spots on lower surface of the leaves (Fig. 1.1). This is more visible only when the leaves are held against sunlight. These spots later changed into visible faint rusty streaks on the under surface of the leaves which is designated as stage 2 (Fig. 1.2). During the next stage of disease development i.e., stage 3, the brown streaks became elongated and appeared on both abaxial and adaxial surface of the leaf (Fig. 1.3). The streaks then developed into elliptical spot surrounded by yellow halo represented as stage 4 (Fig. 1.4). At stage 5, the elliptical spots enlarges into lesions with greyish centers surrounded by definite dark brown borders containing black pin headed like fruiting body embedded in it (Fig. 1.5). When the infection density is high, these lesions coalesced causing complete necrosis of the leaf (stage 6), thereby reducing the photosynthetic area of the leaves which in turn reduced the yield of the crop (Fig. 1.6).

\section{Morphological characters}

The leaf samples treated with $10 \%$ potassium hydroxide when observed under microscope revealed the presence of perithecia like structure which were closely associated with the lesions.

The immature perithecia (Fig. 2.1) appeared to be round in shape whereas mature perithecia (Fig. 2.2) were flask shaped, 30- $40 \mu \mathrm{m}$ wide and were ostiolated. The cracking of mature perithecia resulted in the release of asci (Fig. 2.3) bearing eight ascospores inside it. Each of the ascospores (Fig. 2.4) was 3 septated and was twined around each other. No asexual fungal structures were noticed.

\section{Molecular characterization}

\section{DNA isolation and PCR amplification}

The PCR amplification of rDNA-ITS region of the fungal DNA isolated from the lesions of the banana leaf samples using ITS 1 and ITS 4 primers yielded an amplicon of size 540- 580 bp (Table 2; Fig. 3). The sequence analysis of rDNA-ITS region using BLAST algorithm showed 97 - 100\% sequence homology to Mycosphaerella emusae reported from banana plant.

\section{Phylogenetic analysis}

All the isolates inciting Sigatoka leaf spot disease were grouped into two major clusters $\mathrm{A}$ and B (Fig. 4). The major cluster A was divided into two sub clusters $\mathrm{A} 1$ and $\mathrm{A} 2$. The isolates $M$. emusaeS6, $M$. emusaeS7, $M$. emusaeS2, $M$. emusaeS4, $M$. emusaeS12, $M$. emusaeS5, M. emusaeS11, M. emusaeS10, $M$. emusaeS8, M. emusaeS1 were clustered together in sub cluster A1 showing close evolutionary origin and these isolates were closely associated with the isolate from Trichy (KC966893.1). 
Table.1 Sigatoka leaf spot disease incidence in different agroclimatic zones of Kerala

\begin{tabular}{|c|c|c|c|c|c|}
\hline No: & District of survey & $\begin{array}{l}\text { Stage of } \\
\text { the crop } \\
\text { surveyed } \\
\text { (MAP)* }\end{array}$ & Variety & $\begin{array}{l}\text { Youngest } \\
\text { leaf spot } \\
\text { (YLS) }\end{array}$ & $\begin{array}{l}\text { Disease } \\
\text { severity } \\
\text { index } \\
\text { (DSI) }\end{array}$ \\
\hline S1. & Thrissur, Mellor & 12 & Swarnamuki & 6 & 19.89 \\
\hline S2. & Thrissur, Madakkathara & 7 & Nendran & 10 & 11.78 \\
\hline S3. & Palakkad, Pattambi & 7 & Nendran & 9 & 12.50 \\
\hline S4. & Palakkad, Srikrishnapuram & 5 & Nendran & 10 & 11.30 \\
\hline S5. & Malapuram, Vengara & 10 & Attunendran & 8 & 16.78 \\
\hline S6. & Malapuram, SR Nagar & 5 & Nendran & 10 & 13.48 \\
\hline S7. & Thiruvanathapuram,Peringamala & 5 & Chenkadali & 6 & 27.40 \\
\hline S8. & Thiruvananthapuram,Neyyatinkkara & 8 & Nendran & 11 & 21.79 \\
\hline S9. & Wayanad, Ambalavayil & 9 & Nendran & 6 & 23.41 \\
\hline S10. & Wayanad, Sulthan Bethery & 7 & Nendran & 7 & 19.08 \\
\hline S11. & Ernakulam, Pothanicad & 7 & Nendran & 9 & 18.76 \\
\hline S12. & Ernakulam, Kalady & 5 & Nendran & 10 & 14.84 \\
\hline
\end{tabular}

MAP* - Months after planting

Table.2 Details of primers used

\begin{tabular}{l|l|l|l} 
Target & Primer Name & Direction & Sequence $\left(\mathbf{5}^{\prime} \rightarrow \mathbf{3}^{\prime}\right)$ \\
\hline ITS & ITS-1F & Forward & TCCGTAGGTGAACCTTGCGG \\
& ITS-4R & Reverse & TCCTCCGCTTATTGATATGC
\end{tabular}

Fig.1 Leaves showing different stages of Sigatoka leaf spot symptoms
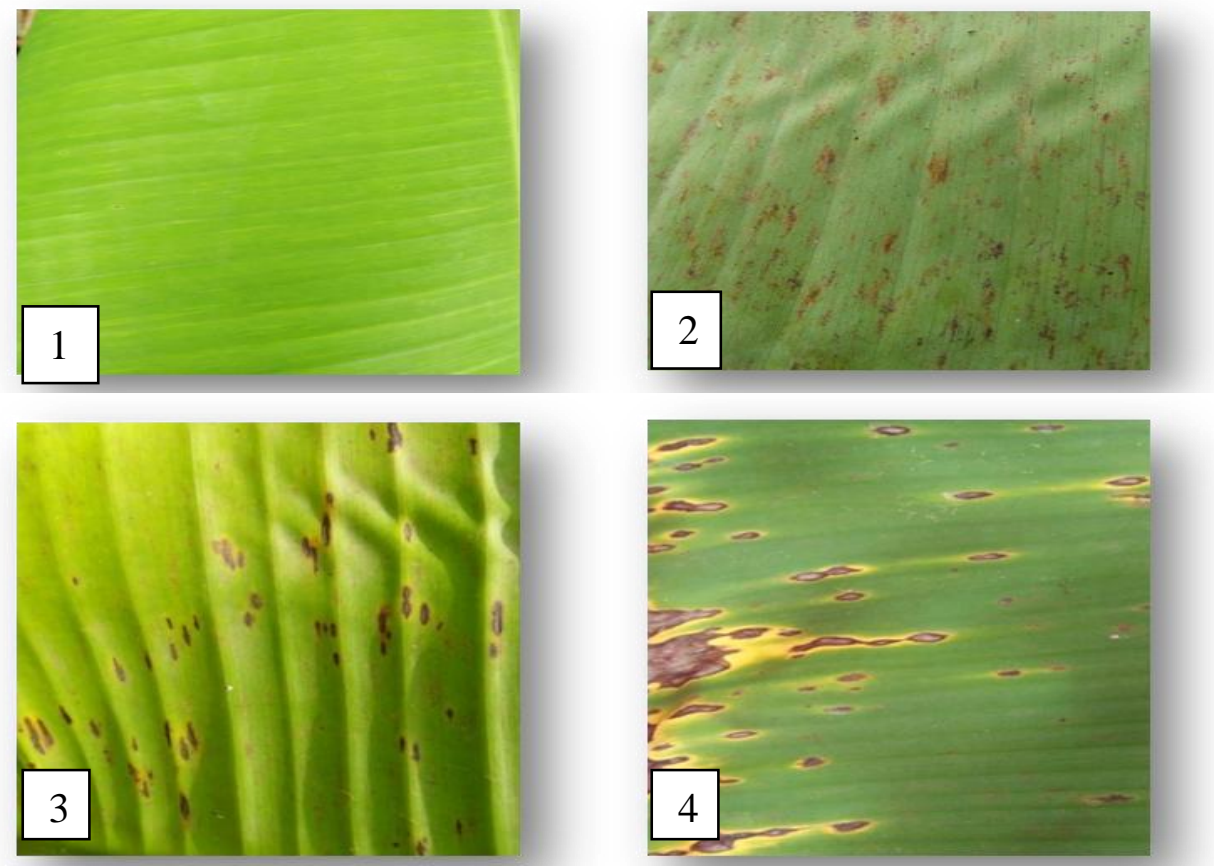
Int.J.Curr.Microbiol.App.Sci (2018) 7(2): 663-670
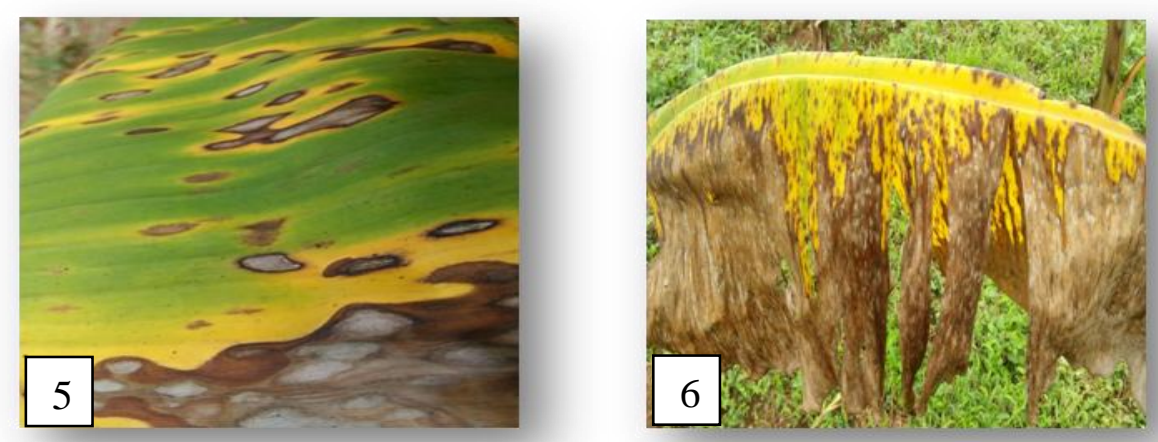

Fig.2 Sexual fruiting body of the pathogen
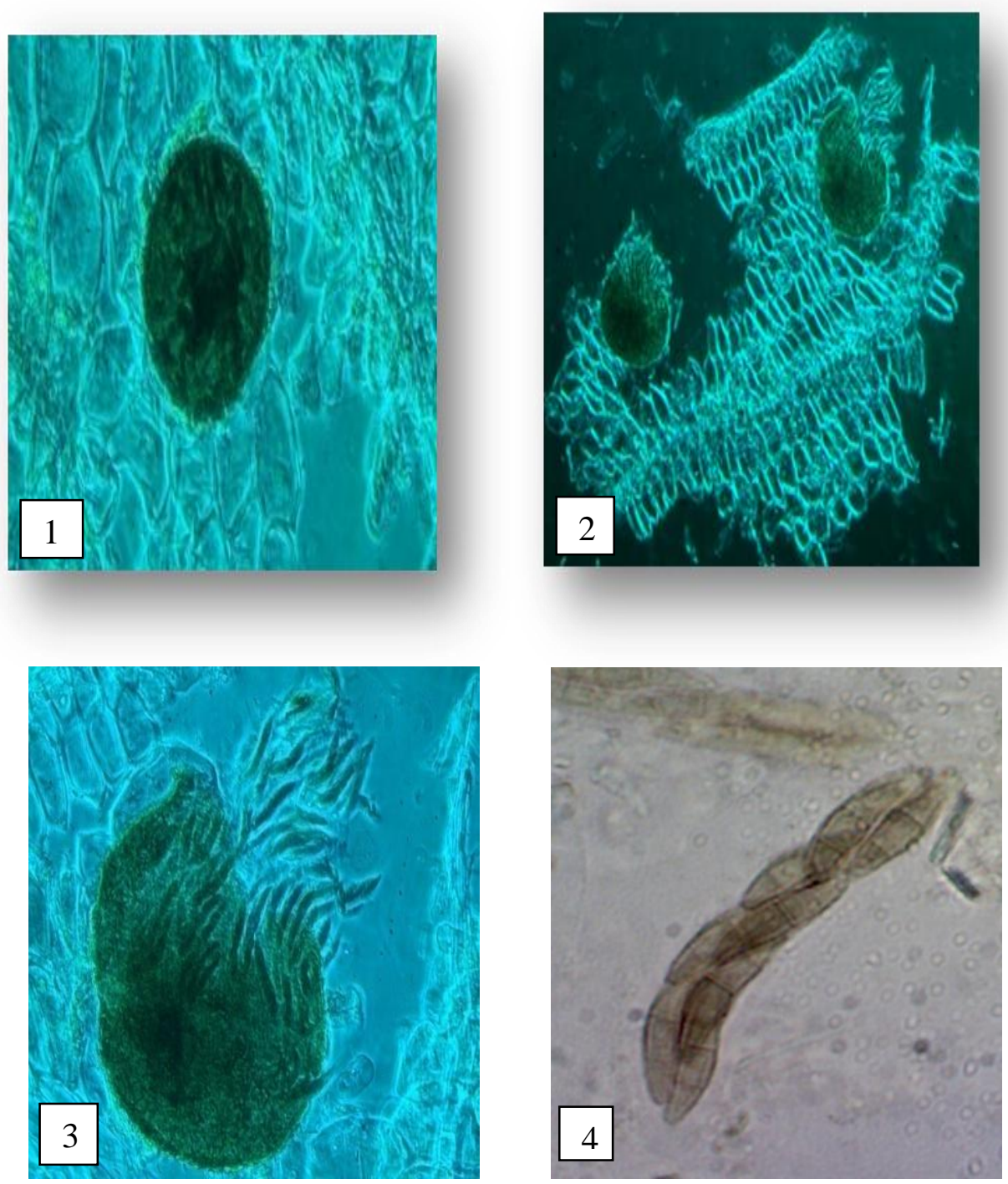
Fig.3 PCR amplicon obtained using ITS 1 and ITS 4 primers

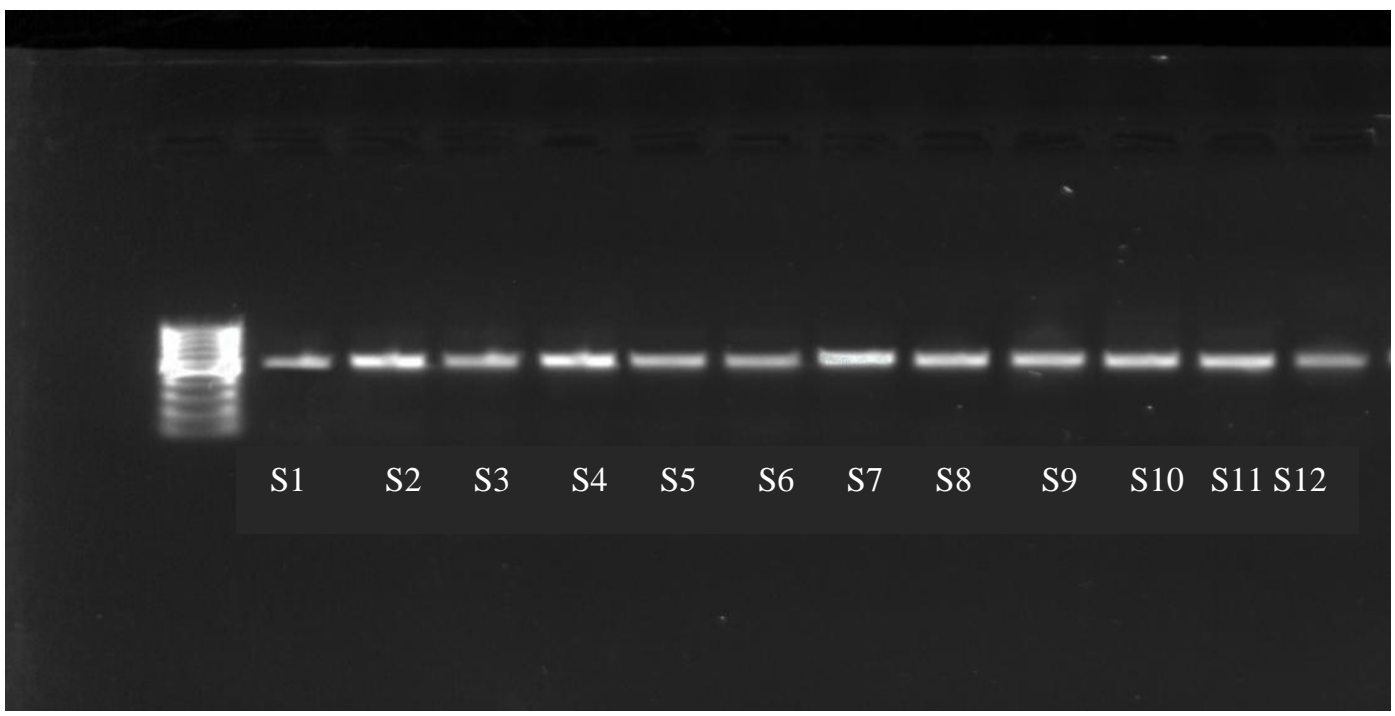

Fig.4 The evolutionary history was inferred using the UPGMA method. The evolutionary distances were computed using the Maximum Composite Likelihood method. Evolutionary analyses were conducted in MEGA6

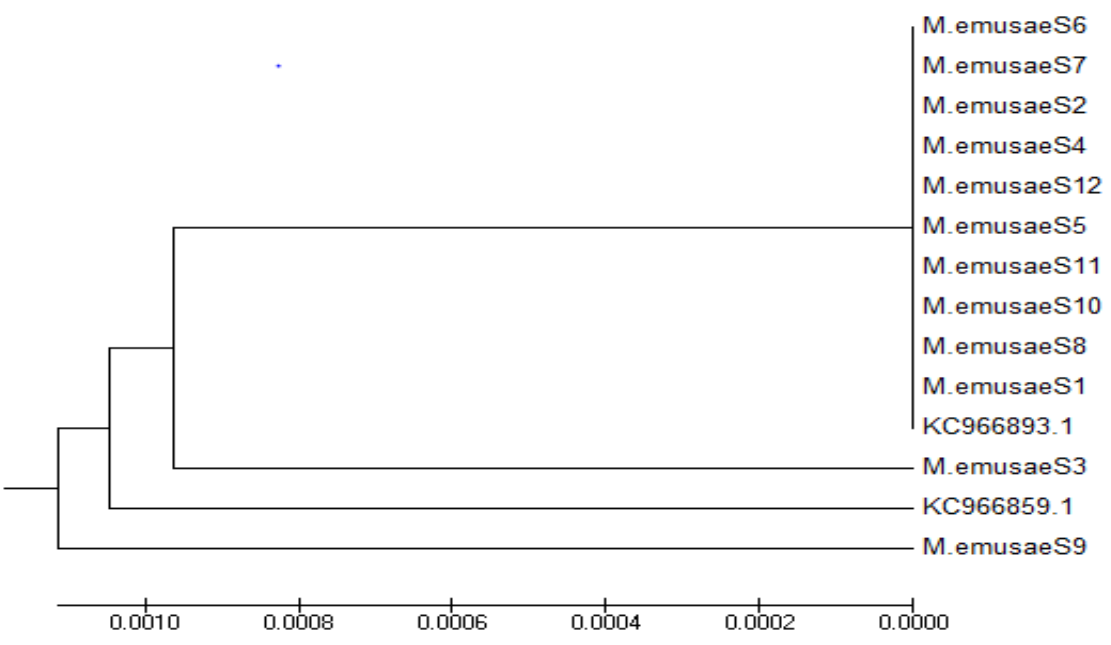

The subcluster A2 contained only one isolate M. emusaeS3 which showed close association to M. emusae (KC966859.1) reported from Trichy on banana. The isolate M. emusaeS9 formed a single cluster B. Hence, the results of phylogenetic analysis indicated the presence of genetic diversity among $M$. emusae isolates collected from different agroclimatic zones of Kerala.

The three species of Mycosphaerella viz., Mycosphaerella fijiensis, M. musicola and $M$. eumusae inciting black Sigatoka, yellow Sigatoka and septoria leaf spot in banana are difficult to identify based on their symptoms and their cultural characters (Carlier et al., 2000a). Therefore, the identification of the fungi associated with Sigatoka leaf spot of banana is very important for the effective management of leaf spot disease of banana, which otherwise result in higher yield reduction. Hence, the pathogen inciting Sigatoka leaf spot disease especially in banana variety Nendran grown in Kerala was 
confirmed by PCR amplification of the rDNA- ITS region of the fungal DNA isolated from lesions of banana leaf collected during survey using ITS 1 and ITS 4 primers which yielded an amplicon of 540-580bp which was in accordance with the result of Devi and Thangavelu (2014). The analyses of the sequences of the amplicon using BLAST algorithm indicated $97-100 \%$ sequence homology to Mycosphaerella emusae reported from India on banana. Carlier et al., (2000b) reported the causal agent of Sigatoka leaf spot disease in Southern India and Southeast Asia as Mycosphaerella emusae based on the sequences of ITS region and $5.8 \mathrm{~S}$ ribosomal DNA regions of the pathogen. Jones (2002) also indicated that M. emusae affected the cultivars which were highly resistant to M.fijiensis and M.musicola and the incidence of $M$. emusae was more prevalent in Southeast Asia. Hence, this study clearly indicates that the fungi associated with Sigatoka leaf spot disease in commercially cultivated varieties of banana in the state of Kerala is M. emusae.

\section{References}

Arzanlou, M., Abeln, E.C.A., Kema, G.H.J., Waalwijk, C., Carlier, J., de Vries, I., Guzmán, M. and Crous, P.W. 2007. Molecular diagnostics for the Sigatoka disease complex of banana.
Phytopathology. 97: 1112- 1118.

Carlier, J., Zapater, M.F., Lapeyre, F., Jones, D.R. and Mourichon, X. 2000b. Septoria leaf spot of banana: A newly discovered disease caused by Mycosphaerella eumusae (Anamorph Septoria eumusae). Phytopathology. 90: 884-890.

Carlier, J., Foure, E. and Gauhl, F. 2000a. Sigatoka leaf spots. In: Abaca and Enset. R. D. Jones (eds.) Diseases of Banana, Wallingford, UK: CABI Publishing. Pp. 37-92.

Ganga Devi, P., and Thangavelu, R. 2014. Genetic diversity analysis of Mycosphaerella eumusae causing Septoria leaf spot disease of banana in India. Indian Phytopath. 67(2):388-395.

Jones, R. D. 2000. Sigatoka leaf spots. In: Abaca and Enset. R. D. Jones (eds.) Diseases of Banana, CABI Publishing, Wallingford, UK. Pp.79-92.

Surridge, A.K.J., Viljoen, A., Crous, P.W. and Wehner, F.C. 2003. Identification of the pathogen associated with Sigatoka disease of banana in South Africa. Aust. Plant Pathol. 32: 27-31.

Udugama, S. 2002. Septoria leaf-spot disease of banana Mycosphaerella eumusae: a new record for Sri Lanka. Annals of the Sri Lanka department of Agriculture. 4: 337-343.

\section{How to cite this article:}

Milsha George, K. Anita Cherian, S. Beena and Namitha, P.M. 2018. Symptomatology and Molecular Characterization of Fungi Associated with Sigatoka Leaf Spot Disease of Banana in Kerala, India. Int.J.Curr.Microbiol.App.Sci. 7(02): 663-670. doi: https://doi.org/10.20546/ijcmas.2018.702.082 